\title{
Controls on mud distribution and architecture along the fluvial- to-marine transition
}

\author{
Wietse I. van de Lageweg $^{1 *}$, Lisanne Braat ${ }^{1}$, Daniel R. Parsons ${ }^{2}$, and Maarten G. Kleinhans ${ }^{1}$ \\ ${ }^{1}$ Faculty of Geosciences, Utrecht University, Princetonlaan 8A, 3584 CB Utrecht, Netherlands \\ ${ }^{2}$ School of Environmental Sciences, University of Hull, Cottingham Road, Kingston-Upon-Hull HU6 7RX, UK
}

\begin{abstract}
The interaction of marine (tides and waves) and fluvial processes determines the sedimentary fill of coastal systems in the fluvial-tomarine (FTM) transition zone. Despite frequent recognition of tidal and wave influence in modern and ancient systems, our understanding of the relative importance of marine processes and their impact on mud deposition and reservoir architecture is limited. This study combined subsurface field observations and numerical simulations to investigate the relative importance of river flow, tides, waves, and mud input in governing the sedimentary fill in funnel-shaped basins along the FTM transition. Model simulations show a self-forming bar-built estuary with dynamic channels and sandy bars flanked by mud flats, which is in agreement with trends observed in nature. From three-dimensional virtual sedimentary successions, statistical tendencies for mud distribution and thickness were derived for the spectrum of marine and fluvial processes, and these values provide quantitative information on the net-to-gross ratio and mud architecture. The relative influence of marine and fluvial processes leads to a predictable facies organization and architecture, with muddier and more heterogeneous sediments toward the flanks. For the first time, our simulations allow the sedimentary fill in basins along the FTM transition to be related explicitly to hydrodynamic conditions, providing new insights into the morphosedimentary evolution of coastal systems, with implications for sequence stratigraphy.
\end{abstract}

\section{INTRODUCTION}

The fluvial-to-marine (FTM) transition represents one of the most dynamic environments on Earth. Driven by the combined actions of river flow, tidal currents, and waves, this zone is characterized by a continuously evolving morphology with strong gradients in flow, salinity, and sediment concentrations, and a host of chemical and biological processes (Dalrymple and Choi, 2007). Following Dalrymple and Choi (2007), the FTM transition is here defined as a zone from a unidirectional river boundary through a mixed-energy region to a fully marine ocean boundary. Depositional environments along the FTM transition such as deltas and estuaries are prominent features in sequence stratigraphic analyses (Dalrymple et al., 1992; MacEachern and Pemberton, 1994), and their ancient deposits host some of the world's largest hydrocarbon resources, such as the Lower Cretaceous Athabasca Oil Sands (Canada; Wightman and Pemberton, 1997).

The relative influence of river flow, waves, and tidal currents determines the type of delta (Galloway, 1975) or estuary and has important

*E-mail: wietse.vandelageweg@gmail.com

CITATION: van de Lageweg, W.I., Braat, L., Parsons, D.R., and Kleinhans, M.G., 2018, Controls on mud distribution and architecture along the fluvial-tomarine transition: Geology, v. 46, p. 971-974, https://doi.org/10.1130/G45504.1. sedimentological consequences. Estuaries differ from deltas in receiving sediment from both fluvial and marine sources (Dalrymple et al., 1992). Two distinct estuarine facies models have been identified to describe the sedimentary fill of confined basins resulting from the interaction of marine and fluvial processes (Dalrymple et al., 1992). First, wave-dominated estuaries typically show a tripartite zonation with a sandy barrier at the mouth and a sandy bayhead delta at the head. In the central, low-energy part of the estuary, fine-grained muds accumulate in a lagoon environment. Second, tide-dominated estuaries have a less pronounced tripartite facies distribution because tidal energy penetrates further than wave energy, and sands can therefore be found in tidal channels along the length of the estuary. These basins are dominantly built of sand with muddy sediments primarily in tidal flats and marshes along the flanks. The two end-member facies models are intergradational due to local factors such as the relative strengths of the fluvial, tidal, and wave forcing mechanisms, sediment availability, and valley shape (Dalrymple et al., 1992). Wave-dominated sedimentary features are commonly preserved within tide-dominated estuarine sequences and vice-versa (Tessier, 2012).

A quantitative understanding of mud deposit thickness, the distribution of muddy sediments, and the ways in which it changes with forcing is currently lacking. Mud layers are potential barriers to subsurface flow, and therefore quantitative information on their thickness and distribution is crucial in the development of reliable reservoir models (Burton and Wood, 2013). Here, we present the results of subsurface field observations and a series of numerical simulations for a range of conditions in wave- and tide-influenced funnel-shaped basins to provide statistics on mud thickness distribution. Specifically, we aimed to (1) quantify mud layer thickness and distribution in the Scheldt estuary across the late Holocene; (2) generate three-dimensional (3-D) virtual sedimentary successions quantifying spatial trends in mud deposition and preservation; (3) evaluate the impact of river flow, waves, tides, and mud supply on mud thickness and distribution; and (4) explore linkages between formative conditions and the resultant morphosedimentary expression along the FTM transition.

\section{APPROACH}

The Scheldt estuary in southwestern Netherlands provides an example of an estuary driven by the combined actions of river flow, tides, waves, and mud supply (van Kessel et al., 2011), and it was selected for its unique availability of high-quality subsurface data (Fig. 1). Cores from the Scheldt estuary were accessed through the DINO (Data and Information on the Dutch Subsurface) portal (https://www.dinoloket.nl/en), a high-density subsurface data set containing information on stratigraphy and lithology. A subselection of 756 cores fell within the modern Scheldt estuary region of interest, which was reduced to 547 cores incorporating late Holocene (NaWa Formation) deposits. Within these late Holocene deposits, which integrate a variety of coastal depositional environments 

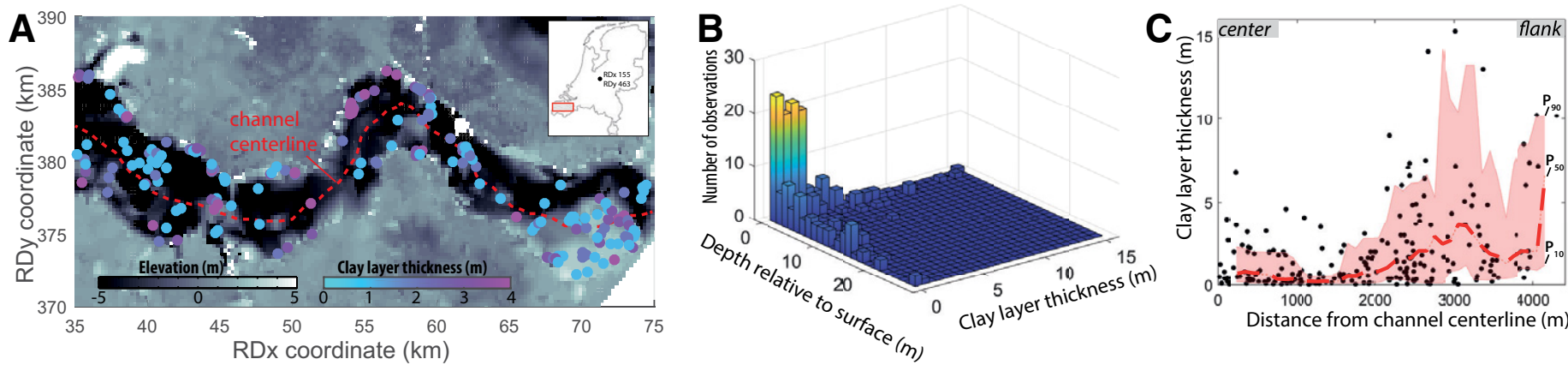

Figure 1. Clay deposition in western Scheldt estuary in southwestern Netherlands. A: Spatial distribution of clay layer thickness within late Holocene deposits in modern Scheldt estuary. Center of Dutch RD coordinate system is located in Amersfoort, with coordinates $x=155$ km and $y=463 \mathrm{~km}$. B: Two-dimensional histogram of clay layer thickness observations $(n=227)$ and their depth relative to surface. Top of clay layer was used to calculate depth. C: Clay layer thickness as a function of lateral distance from channel centerline (see A) of modern Scheldt estuary. Clay thickness shows an increase toward flanks, as described by 10th (lower pink line), 50th (dashed red line), and 90th percentiles (upper pink line) of thickness observations (black dots) using a moving window (window size is $500 \mathrm{~m}$ at $100 \mathrm{~m}$ intervals).

along the FTM transition (Vos, 2015), 227 cores contained clay deposits. Clay (diameter $[D]<2 \mu \mathrm{m}$ ) deposits within the DINO data set are defined as layers consisting of at least $8 \%$ clay, indicating that these layers can also contain silt and sand. The average core thickness of the 547 cores was $19.4 \mathrm{~m}$, with an average layer thickness of $1.05 \mathrm{~m}$, following standardized interpretation for inclusion in the DINO portal. Because only $10 \%$ of the layers were thinner than $0.14 \mathrm{~m}$, we focused on the thicker $(>0.1 \mathrm{~m})$ clay layers, in agreement with our aim to quantify the large-scale trends in thickness and distribution of clay deposits along the FTM transition.

We applied the state-of-the-art, open-source modeling package Delft3D, version 4.01.00 (Lesser et al., 2004), to systematically examine the effects of river flow, tides, waves, and mud supply on the structure of sedimentary fill within idealized basins along the FTM transition. The model domain was $30 \times 15 \mathrm{~km}$, consisting of a $10 \times 15 \mathrm{~km}$ ocean and a funnel-shaped basin with a headward exponential decrease in width (Savenije, 2015) and a depositional slope of 0.0002 . The focus of our analyses was the preserved sedimentary fill within the funnel-shaped basin (i.e., excluding the ebb-tidal delta) as a function of river flow $\left(0-100 \mathrm{~m}^{3} / \mathrm{s} ; 0.25-3000 \mathrm{~m}^{3} / \mathrm{s}\right.$ for temperate estuaries; Prandle et al., 2005), tidal range ( $0-3 \mathrm{~m}$; mesotidal, decreasing into the basin, i.e., a hyposynchronous basin), wave height $\left(H_{\text {sig }}\right)$ of $0.7 \mathrm{~m}$, with a wave period $\left(T_{\text {peak }}\right)$ of $6 \mathrm{~s}$, coast-normal; low wave energy; Wright and Short, 1984), mud source (marine or fluvial), mud input $(0-50 \mathrm{mg} / \mathrm{L}$; $32 \mathrm{mg} / \mathrm{L}$ observed mean value in Dovey estuary, Wales, UK; Braat et al., 2017), and a constant sea level. Based on the relative intensity of river, tide, and wave processes, all simulations can be considered mixed-energy coastal systems (Dalrymple et al., 1992), except for Run021 with river flow only.

Cohesive sediment, i.e., mud, is defined as a mixture of the clay and silt fractions. The cohesive nature causes complex processes affecting the erosion and deposition of sediments, requiring the bed composition to be incorporated in morphological predictions of mixed sediments (van Kessel et al., 2011). The Engelund and Hansen (1967) equation was used to calculate sediment transport for the noncohesive sand (median diameter $\left.\left[D_{50}\right]=300 \mu \mathrm{m}\right)$ beds, while the Partheniades-Krone formulation (Partheniades, 1965) was applied to describe the interactive mud and sand fluxes for cohesive beds. Note that we use clay only when referring to the Scheldt data set and mud in all other cases. Simulation duration (5 hydrodynamic years using a morphological time-scale factor of 400 [Roelvink, 2006], nominally equivalent to a scaled period of $2000 \mathrm{yr}$ of bar deposits) was sufficient for a dynamic landscape to evolve, with bars similar in size to those found in natural confined basins (Leuven et al., 2016). Additional details of model setup and approach with analyses of the hydrodynamics, sediment transport, and morphodynamic evolution of all simulations have been described by Braat et al. (2017).

Sequential digital elevation models (DEMs) of the bar and channel morphology were used to generate a virtual stratigraphic record following approaches outlined in van de Lageweg et al. (2013). Approximately 5000 virtual cores were constructed for each time step, containing information on bar thickness, time of deposition, deposition rate, and mud fraction. We identified a mud layer when the dominant fraction (i.e., mud fraction $>50 \%$ ) was composed of mud. Integration of all individual virtual cores resulted in 3-D virtual stratigraphic successions for all model scenarios, which were then quantitatively compared using probability distributions, maps, and cross sections.

\section{RESULTS AND DISCUSSIONS}

\section{Scheldt Estuary}

The Scheldt estuary is dominantly built of sand, with clay deposits representing $~ 5 \%$ of the total sediment volume (Table 1), which is consistent with Scheldt surface observations of muddy sediments (Maldegem et al., 1993). Clay layers have an average thickness of $1.2 \mathrm{~m}$ in the Scheldt estuary (Fig. 1A), with a distribution skewed toward thinner layers (Fig. 1B). Fifty percent $(50 \%)$ of the clay layers are thinner than $0.5 \mathrm{~m}$, and $80 \%$ of the layers have a thickness between $0.06 \mathrm{~m}$ and $3.1 \mathrm{~m}$ (Table 1). The clay deposits are typically (85\%) stacked into a single layer toward the top of some cores. Spatially, clay-layer thickness increases toward the mouth (Fig. 1A; on average, from $1.3 \mathrm{~m}$ near the head to $2.7 \mathrm{~m}$ near the mouth; see also Item DR1 in the GSA Data Repository ${ }^{1}$ ) as well as toward the flanks of the estuary, where the clay is stored in mud flats (Fig. 1C).

TABLE 1. DESCRIPTIVE STATISTICS OF MUD DEPOSITION IN SCHELDT ESTUARY AND NUMERICAL SIMULATIONS

\begin{tabular}{lcccccc}
\hline \hline Model ID & & $\begin{array}{c}\text { NTG } \\
(\mathbf{\%})\end{array}$ & $\begin{array}{c}\boldsymbol{P}_{10} \\
(\mathbf{m})\end{array}$ & $\begin{array}{c}\boldsymbol{P}_{50} \\
(\mathbf{m})\end{array}$ & $\begin{array}{c}\boldsymbol{P}_{90} \\
(\mathbf{m})\end{array}$ & $\begin{array}{c}\boldsymbol{P}_{\max } \\
(\mathbf{m})\end{array}$ \\
\hline Scheldt estuary & Default, fluvial mud & 95 & 0.06 & 0.5 & 3.1 & 14.1 \\
Run001 & Marine mud & 87 & 0.01 & 0.19 & 0.88 & 2.98 \\
Run002 & No mud, sand only & 96 & 0.02 & 0.43 & 3.22 & 3.59 \\
Run003 & 100 & - & - & - & - \\
Run004 & Fluvial and marine mud & 77 & 0.03 & 0.30 & 1.93 & 6.89 \\
Run008 & Larger river flow & 89 & 0.02 & 0.21 & 0.67 & 1.98 \\
Run009 & Larger mud input & 74 & 0.03 & 0.39 & 1.56 & 3.62 \\
Run010 & Smaller mud input & 95 & 0.01 & 0.14 & 0.45 & 3.54 \\
Run021 & No tides & 78 & 0.03 & 0.26 & 0.85 & 2.53 \\
Run025 & Fluvial and marine mud and waves & 99 & 0.05 & 0.15 & 0.43 & 1.47 \\
Run029 & Fluvial mud and waves & 96 & 0.02 & 0.13 & 0.44 & 1.23 \\
\hline
\end{tabular}

Note: Net-to-gross (NTG) represents the percentage sand in the reservoir, and $P$ values correspond to the $10^{\text {th }}, 50^{\text {th }}$, and $90^{\text {th }}$ percentiles and maximum value of the mud-layer thickness distribution (for full distributions, see Fig. 3).

${ }^{1}$ GSA Data Repository item 2018369, Figures DR1 and DR2, and animated videos visualizing the full three-dimensional virtual bar sedimentology for all simulations (videos DR3-DR12), is available online at http://www.geosociety.org /datarepository/2018/ or on request from editing@geosociety.org. 


\section{Numerical Simulations}

The default run shows a self-confining bar-built basin fill with dynamic channels and sandy bars flanked by mud flats (Fig. 2). These morphosedimentary trends are consistent with the aforementioned observations from the Scheldt estuary and facies zonation for tide-dominated estuaries (Dalrymple et al., 1992). Bars are generally between $1 \mathrm{~m}$ and $3 \mathrm{~m}$ in thickness and tend to thicken toward the mouth due to an increase in accommodation space (Fig. 2). The basin fill is dominantly composed of sand (Table 1;87\%), with mud primarily stored in mud flats toward the flanks (Fig. 3A). Fifty percent $(50 \%)$ of the mud layers are thinner than $0.19 \mathrm{~m}$ (Fig. 3C), and $80 \%$ of the layers have a thickness between $0.01 \mathrm{~m}$ and $0.88 \mathrm{~m}$ (Fig. 3; Table 1). The mud deposits are typically ( $80 \%)$ stacked into a single layer toward the top of the cores, in agreement with Scheldt observations and consistent with previous studies of the fluvio-tidal transition (Dashtgard and La Croix, 2015).

The amount of mud supply has significant effects on the shape of the basin (Fig. 3) and the thickness and distribution of mud deposits (Table 1). In the absence of mud, bank stability is limited, resulting in a wider basin with more parallel channels and bars of lower elevation. A larger mud input results in thicker and larger mud flats, which are difficult to erode and therefore lead to a narrower and smaller basin. This observation highlights the intimate link between morphological processes and sedimentary products and the crucial role of mud supply.

The source of the mud also affects basin development and mud architecture. For marine mud, mud flats are only formed in the lower basin when there is sufficient flood flow to transport the mud headward. In contrast, fluvial mud is distributed in mud flats along the entire length of the basin (Fig. 3A). Mud deposits associated with a marine source are generally thicker $\left(50^{\text {th }}\right.$ percentile of mud thickness distribution $P_{50}=$ $0.43 \mathrm{~m})$ compared to mud deposits with a fluvial source $\left(P_{50}=0.19 \mathrm{~m}\right)$ due to the larger accommodation space toward the mouth (Table 1). Mud supply from fluvial and marine sources has a combined effect, with mud distributed along the entire basin and deposits becoming muddier toward the mouth, which is consistent with FTM mud trends observed along the lower Fraser River (Dashtgard and La Croix, 2015).

River flow, tides, and waves have different effects on mud thickness and distribution. More and larger mud flats are formed for a higher river flow, although the mud thickness statistics remain similar (Table 1). Tidal amplitude also affects mud-flat size but not mud-layer thickness. With lower tidal amplitudes, intertidal area is smaller, limiting the space for mud flats, while higher tidal flow velocities resulting from higher tidal amplitudes prevent deposition of mud. Importantly, our simulations show that the relative strength of tidal and fluvial currents determines the style of the sedimentary fill as well as the distribution of mud within the basin (Figs. 3A and 3B). For more river-dominated basins, higher river flow
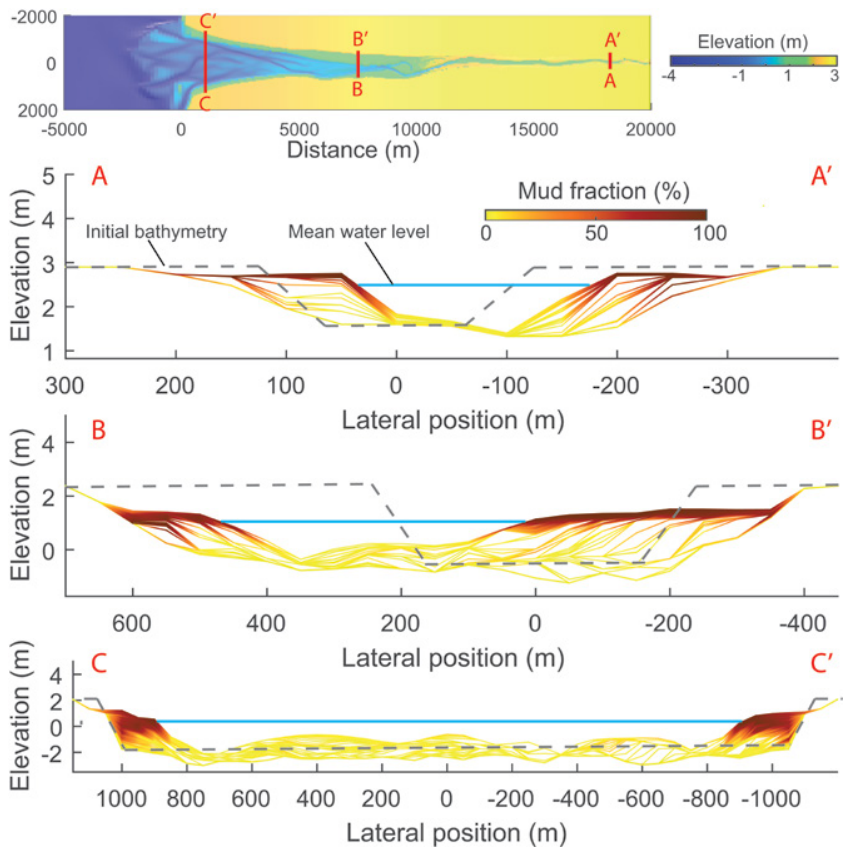

Figure 2. Virtual bar sedimentology showing cross sections populated with mud fraction for a basin with fluvial and tidal forcing and default mud input (Run001). Elevation lines in cross sections $A-A^{\prime}, B-B^{\prime}$, and $C-C^{\prime}$ are populated with mud fraction (which is what a gamma-ray plot would usually reflect, i.e., a higher gamma ray index is indicative of a higher mud volume) to combine morphological and sedimentological information, while their orientation can be used to track migration of bars. Initial bathymetry (gray dashed line) and mean water level (blue solid line) are also indicated. Note that the digital elevation model shows a portion of the full model domain of $30 \mathrm{by} 15 \mathrm{~km}$. Animated videos slicing full three-dimensional virtual bar sedimentology for all simulations are available in the Data Repository (see footnote 1).

results in stronger tidal damping (Horrevoets et al., 2004), reducing the tidal prism and tidal velocity. As a consequence, river sediment discharge fills up the basin through a deltaic coarsening-upward succession with mud at the base (item DR10). Such a sedimentary succession is consistent with observations from modern and ancient river-dominated prograding deltas (Dalrymple et al., 1992; Allen and Posamentier, 1993). Waves cause a widening of the mouth and limit the deposition of mud due to higher tidal flood flow velocities. Consequently, mud flats are deposited $5 \mathrm{~km}$ farther headward, although the reservoir is sandier compared to the run without waves, and the preserved mud layers are thinner (Table 1).
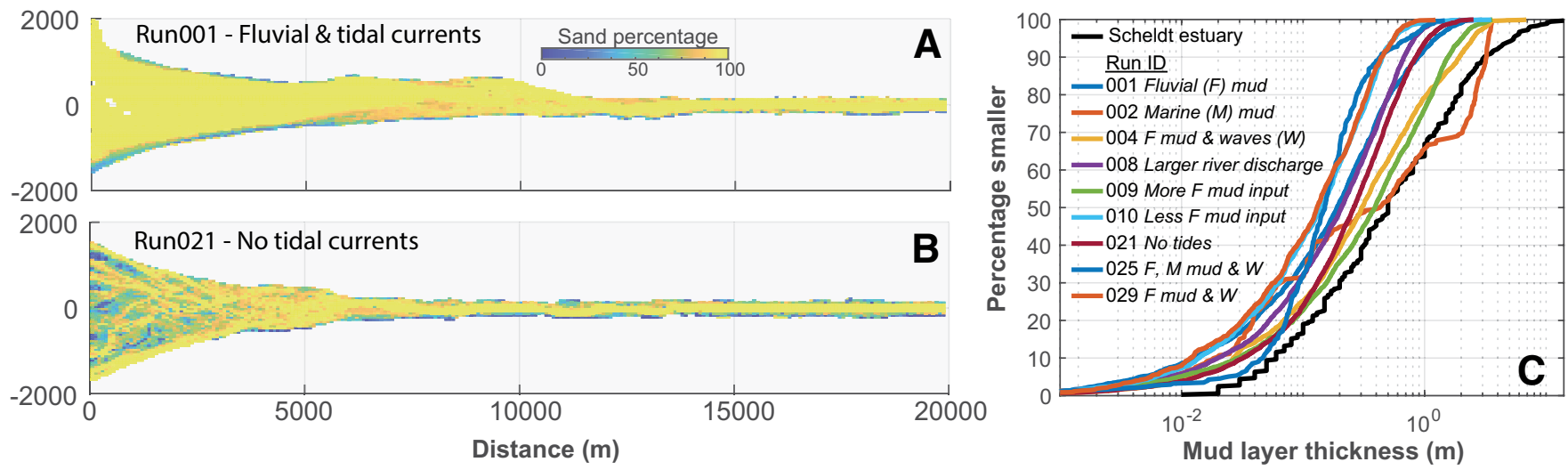

Figure 3. Mud deposition in numerical simulations and spatial distribution of percentage sand in core. A: Predominantly mud deposition along flanks of the basin for Run001 with mixed fluvial and tidal currents. B: Heterogeneous mud deposition for Run021 without tides. C: Cumulative probability distribution (cdf) of mud layer thickness observed in numerical simulations, along with cdf of clay layer thickness in Scheldt estuary (see also Fig. 1; Table 1). 
Our simulations indicate statistical tendencies in the spatial distribution of sand and mud deposits as a function of the interaction between fluvial and marine processes, and they provide quantification of the resultant mud architecture. River-dominated basins generate deltaic sedimentary successions with a heterogeneous and muddier architecture toward the mouth, leading to increased compartmentalization (Fig. 3B). Tides tend to separate sandy and muddy facies and primarily store mud in flats along the flanks of the basin (Fig. 3A). The addition of low-energy fair-weather waves is insufficient to form a wave-built barrier, but it prevents mud deposition in the mouth region, resulting in a sandier reservoir (Table 1) with mud flats restricted toward the head. Notably, our simulations show that similar reservoir bulk properties can be obtained for different hydrodynamic conditions and combinations (Table 1). This model outcome implies that bulk properties are insufficient to characterize reservoir architecture, and spatially explicit methods as shown in this study are required to provide accurate solutions. Furthermore, our simulations indicate that a higher river flow or larger mud input leads to self-confinement and fill of the basin that can transform an estuary into a delta, even in the absence of sea-level rise (Dalrymple et al., 1992; Boyd et al., 1992). This finding demonstrates that a change in mud supply or hydrodynamic conditions can result in distinctly different morphosedimentary expressions, highlighting the need for and potential of process-based models to further our quantitative understanding of the FTM transition.

\section{CONCLUSIONS}

Our study quantifies the importance of river flow, waves, tides, and mud supply in shaping the geometry and sedimentary architecture of funnel-shaped basins along the FTM transition. Three-dimensional modeled stratigraphic successions show formation of a self-confining bar-built basin fill with dynamic channels and sandy bars flanked by mud flats. Obtained statistics provide quantification of mud thickness and distribution in a coastal system. The relative influence of fluvial and marine processes leads to a predictable variation in facies characteristics and stratigraphic organization, with a muddier and more compartmentalized architecture toward the mouth and flanks, consistent with subsurface observations made in the Scheldt estuary. A key finding of our simulations is the roles of mud supply and hydrodynamic conditions in the development of coastal systems, i.e., potentially transforming estuaries into deltas in the absence of a change in sea level, which has implications for sequence-stratigraphy studies. With virtually unlimited exposure in three dimensions, a spatial link between the spectrum of flow conditions and resultant mud architecture was established, highlighting the key role that process-based models can play in predicting the sedimentary fill along the FTM transition.

\section{ACKNOWLEDGMENTS}

Lageweg, Braat, and Kleinhans were supported by the Dutch Technology Foundation (STW) of the Netherlands Organization for Scientific Research (NWO) through Vici-grant 0.16.140.316/13710 to Kleinhans. Parsons recognizes a European Research Council Consolidator Award (725955). We thank K. Choi, B. Dalrymple, S. Dashtgard, and two anonymous reviewers for comments that improved the manuscript.

\section{REFERENCES CITED}

Allen, G.P., and Posamentier, H.W., 1993, Sequence stratigraphy and facies model of an incised valley fill: The Gironde estuary, France: Journal of Sedimentary Research, v. 63, p. 378-391.

Boyd, R., Dalrymple, R.W., and Zaitlin, B.A., 1992, Classification of clastic coastal depositional environments: Sedimentary Geology, v. 80, no. 3-4, p. 139-150, https://doi.org/10.1016/0037-0738(92)90037-R.

Braat, L., van Kessel, T., Leuven, J.R.F.W., and Kleinhans, M.G., 2017, Effects of mud supply on large-scale estuary morphology and development over centuries to millennia: Earth Surface Dynamics, v. 5, no. 4, p. 617-652, https://doi.org /10.5194/esurf-5-617-2017.
Burton, D., and Wood, L.J., 2013, Geologically-based permeability anisotropy estimates for tidally-influenced reservoirs using quantitative shale data: Petroleum Geoscience, v. 19, p. 3-20, https://doi.org/10.1144/petgeo2011-004.

Dalrymple, R.W., and Choi, K., 2007, Morphologic and facies trends through the fluvial-marine transition in tide-dominated depositional systems: A schematic framework for environmental and sequence-stratigraphic interpretation: Earth-Science Reviews, v. 81, p. 135-174, https://doi.org/10.1016/j.earscirev 2006.10.002.

Dalrymple, R.W., Zaitlin, B.A., and Boyd, R., 1992, Perspective estuarine facies models: Conceptual basis and stratigraphic implications: Journal of Sedimentary Petrology, v. 62, p. 1130-1146, https://doi.org/10.1306/D4267A69-2B26 -11D7-8648000102C1865D.

Dashtgard, S.E., and La Croix, A.D., 2015, Sedimentological trends across the tidal-fluvial transition, Fraser River, Canada: A review and some broader implications, in Ashworth, P.J., Best, J.L., and Parsons, D.R., eds., FluvialTidal Sedimentology: Amsterdam, Netherlands, Elsevier, Developments in Sedimentology Volume 68, p. 111-126.

Engelund, F., and Hansen, E., 1967, A Monograph on Sediment Transport in Alluvial Streams: Copenhagen, Denmark, Teknisk Forlag, 62 p.

Galloway, W.D., 1975, Process framework for describing the morphologic and stratigraphic evolution of deltaic depositional systems, in Broussard, M.E., ed., Deltas, Models for Exploration: Houston, Texas, Houston Geological Society, p. 86-98.

Horrevoets, A.C., Savenije, H.H.C., Schuurman, J.N., and Graas, S., 2004, The influence of river discharge on tidal damping in alluvial estuaries: Journal of Hydrology, v. 294, no. 4, p. 213-228, https://doi.org/10.1016/j.jhydrol .2004.02.012.

Lesser, G., Roelvink, J., van Kester, J., and Stelling, G., 2004, Development and validation of a three-dimensional morphological model: Coastal Engineering, v. 51, p. 883-915, https://doi.org/10.1016/j.coastaleng.2004.07.014.

Leuven, J.R.F.W., Kleinhans, M.G., Weisscher, S.A.H., and van der Vegt, M., 2016, Tidal sand bar dimensions and shapes in estuaries: Earth-Science Reviews, v. 161, p. 204-223, https://doi.org/10.1016/j.earscirev.2016.08.004.

MacEachern, J.A., and Pemberton, S.G., 1994, Ichnological aspects of incised valley fills from the Viking Formation of the Western Canadian Sedimentary Basin, in Boyd, R., Zaitlin, B.A., and Dalrymple, R.W., eds., Incised-Valley Systems: Origins and Sedimentary Sequences: Society for Sedimentary Geology (SEPM) Special Publication 51, p. 129-157, https://doi.org/10.2110 /pec.94.12.0129.

Maldegem, D.C., Mulder, H.P.J., and Langerak, A., 1993, A cohesive sediment balance for the Scheldt estuary: Netherlands Journal of Aquatic Ecology, v. 27, no. 2-4, p. 247-256, https://doi.org/10.1007/BF02334788.

Partheniades, E., 1965, Erosion and deposition of cohesive soils: Journal of the Hydraulics Division, ASCE, v. 91, p. 105-139.

Prandle, D., Lane, A., and Manning, A.J., 2005, Estuaries are not so unique: Geophysical Research Letters, v. 32, no. 23, L23614, https://doi.org/10.1029 /2005GL024797.

Roelvink, J.A., 2006, Coastal morphodynamic evolution techniques: Coastal Engineering, v. 53, no. 2, p. 277-287, https://doi.org/10.1016/j.coastaleng.2005.10.015.

Savenije, H.H.G., 2015, Prediction in ungauged estuaries: An integrated theory: Water Resources Research, v. 51, no. 4, p. 2464-2476, https://doi.org/10.1002 /2015WR016936.

Tessier, B., 2012, Stratigraphy of tide-dominated estuaries, in Davis, R.A., Jr., and Dalrymple, R.W., eds., Principles of Tidal Sedimentology: Dordrecht, Netherlands, Springer, p. 109-128.

van de Lageweg, W.I., Van Dijk, W.M., and Kleinhans, M.G., 2013, Channel belt architecture formed by a meandering river: Sedimentology, v. 60, p. 840-859, https://doi.org/10.1111/j.1365-3091.2012.01365.x.

van Kessel, T., Vanlede, J., and de Kok, J., 2011, Development of a mud transport model for the Scheldt estuary: Continental Shelf Research, v. 31, p. 165-181, https://doi.org/10.1016/j.csr.2010.12.006.

Vos, P.C., 2015, Origin of the Dutch Coastal Landscape: Long-Term Landscape Evolution of the Netherlands during the Holocene, Described and Visualized in National, Regional and Local Paleogeographical Map Series: Utrecht, Netherlands, Utrecht University, 359 p., https://doi.org/10.2307/j.ctt2204s8d.

Wightman, D.M., and Pemberton, S.G., 1997, The Lower Cretaceous (Aptian) McMurray Formation: An overview of the Fort McMurray area, northeastern Alberta, in Pemberton, S.G., and James, D.P., eds., Petroleum Geology of the Cretaceous Mannville Group, Western Canada: Canadian Society of Petroleum Geologists Memoir 18, p. 312-344.

Wright, L.D., and Short, A.D., 1984, Morphodynamic variability of surf zones and beaches: A synthesis: Marine Geology, v. 56, no. 1-4, p. 93-118, https://doi .org/10.1016/0025-3227(84)90008-2.

Printed in USA 